\title{
Future Teachers' Training in Identification and Development of IT Giftedness at Schools of the Republic of Tyva
}

\author{
Dolaana O. Kuulara ${ }^{a}$, Marina I. Ragulina ${ }^{b}$ \\ and Mikhail P. Lapchik \\ ${ }^{a}$ Tuvan State University \\ 36 Lenina Str., Kyzyl, 667000, Russia \\ ${ }^{b}$ Omsk State Pedagogical University \\ 14 Tukhachevsky emb., Omsk, 644099, Russia
}

Received 23.07.2019, received in revised form 26.08.2019, accepted 06.09.2019

The article studies the issue of future bachelors' of education professional training improvement (education profile - "computer science") in order to identify and develop children's IT-giftedness in cultural and educational environment of the Republic of Tyva. The research aims at developing the supplement to the system of methodical training, the use of which will ensure the future bachelors' willingness to identify and develop the Tuvan students' IT-giftedness in the course of teaching Computer Science.

Dynamics of changes in the future bachelors' training is determined during the pedagogical experiment, based on a set of empirical methods (observation, questionnaire survey, testing, prolonged pedagogical experiment, the method of expert evaluation, self-evaluation) as well as statistical ones (measurement and mathematical processing of experimental data).

The authors propose to introduce additional components (the complex of methodically oriented courses) to the curriculum, the courses based on ethno-psychological, ethno-cultural, ethnosocial features of Tuvan cultural and educational environment. Effectiveness of the approach, proposed for the bachelors' of computer science improved training for working with gifted children in Tuvan schools, is experimentally proved.

Keywords: bachelor of education, information technologies, giftedness, ethno-psychological, ethno-cultural, ethno-sociocultural features, cultural and educational environment of the Tyva Republic.

Research area: pedagogy.

Citation: Kuular, D.O., Ragulina, M.I., Lapchik, M.P. (2019). Future teachers' training in identification and development of IT giftedness at schools of the Republic of Tyva. J. Sib. Fed. Univ. Humanit. soc. sci., 12(9), 1659-1669. DOI: 10.17516/1997-1370-0483.

(C) Siberian Federal University. All rights reserved

* Corresponding author E-mail address: ragulina@omgpu.ru; lapchik@omsk.edu ORCID: 0000-0002-0103-1103 (Lapchik); 0000-0003-0313-9721 (Ragulina); 0000-0003-0927-2507 (Kuular) This work is licensed under a Creative Commons Attribution-NonCommercial 4.0 International License (CC BY-NC 4.0). 


\section{Introduction}

In broad terms giftedness is a systemic quality that characterizes the child's psyche as a whole (Bogoiavlenskaia, 2004), in a narrower sense it is a combination of abilities enabling a successful performance of a certain activity. The term "giftedness in the field of information technologies" (IT-giftedness) carries the connotation of a person's special abilities in the field of information technologies and distinguishes those who qualitatively differ from their peers in this area. It is IT-giftedness that makes it possible to achieve outstanding results (in comparison with those of other children) in practical and cognitive activities related to search, processing, storage, transmission, and presentation of information while using a computer and applying information and communication technologies.

From the beginning of the 1980s, in many countries (America, England, Germany, Austria, Belgium, France, Italy, Hungary, and Poland) they use the approaches of identification and teaching the gifted students. In our country, the work with gifted children and young people got its relevance a little later: the Federal target programme "Children of Russia" (1996) can be considered the starting point, which now has got its priority position in the state educational policy.

\section{Theoretical framework}

The character of researches in the field of giftedness is quite old and multifaceted (Malikova, Khristoforova, 2017). Understanding of children's giftedness as their potential and favorable internal preconditions of mental development was recognized by many Russian and foreign psychologists: B. G. Anan'ev, N. S. Leites, S. L. Rubinshtein, J. Renzulli, A. Shwedel, R. Sternberg, et al. This means that implementation of giftedness in achievements and its manifestation as a potential require certain external conditions. Consequently, work with gifted children is not limited to the selection and promotion of those who have already shown their giftedness, but is largely associated with the creation of conditions for the children's potential disclosure in accordance with their high level of abilities, desire for knowledge and research activity (Shcheblanova, 2018). It is about creating special conditions at school and in the family that make it possible to reveal and develop giftedness, protect it from possible dangers accompanying or even hindering the child's creative development. It is vital to pay attention to the promotion of giftedness through the study and understanding of a gifted child's problems in various spheres of their life (Sudneva, 2012). 
Although giftedness is common to all peoples, yet, the system of values adopted in a particular culture can both help and impede the manifestation and development of children's giftedness (Agalakova, Luchinina, 2018). In this regard, the central conceptual basis of our research is the ethno-pedagogical approach (Oorzhak, Oorzhak, 2019).

Identification of gifted children, organization of systematic work with them is one of the main tasks of modern school. Gifted children need individualized educational programmes; thus, teachers working with such children need special training (Guseva et al., 2016). In order to get involved in the work with gifted children from the very beginning of their professional activity, the students of pedagogical universities should get specialized training during their studies (Popova, Khieu, 2011). The teachers' professional and personal training in working with gifted children contributes to the effectiveness of talented young people's training and education, so design and implementation of various variable models of training in the context of identifying and developing children's giftedness is an urgent task of vocational education (Krivun', 2014) in conditions of competence and activity approaches.

According to most foreign and Russian researchers, one of the main features of a gifted child's emotional sphere development is increased vulnerability. In J. Freeman's studies we find information that gifted children constantly face emotional and social difficulties (Freeman, 2011).

\section{Problem statement}

An important role in the processes of psychosocial adaptation is played by the person's individual-and-typological characteristic features that determine their relationships with the environment (Buduk-ool, Aizman, 2009; Buduk-ool, 2017; Maryukhina, Munzuk, 2018). The Republic of Tyva is the place with severe climatic conditions. Its individual-personal specificity that affects adaptation covers the so-called "national characteristics". They can be divided into three groups: ethnopsychological (calmness, silence, slowness, isolation, and self-doubt), ethno-cultural (modesty, restraint in communication, restraint in showing one's feelings), and ethnosociocultural (tribal collectivism, desire not to show off, dependence on the opinions of the people around).

Since emotional factors are of a large value even in adaptation to training, not to mention the manifestation of signs of potential giftedness, we argue that the Tuvans' national peculiarities are often a limiting factor in giftedness manifestation and development. 
Support for gifted children is the most important task of modern Russian education. It is solved at the state level and is considered a priority direction of socio-economic development of Russia (Zakirov, Berman, 2014).

Intensive informatization of many areas of human activity suggests an important role of information technologies and IT-gifted people that contribute to the country's socio-economic development. It also implies that highly qualified IT specialists determine global competitiveness of Russia in many areas. In this regard, the issue of training future teachers of computer science for working on identification and development of children's giftedness in the field of information technologies, the solution of which can subsequently increase the chance of qualified IT-specialists in Russia. This issue should be considered not only Russia-wide, but also in the context of cultural and educational environment of the regions, the Tyva Republic being one of them (Karelina, 2018; Nikitina, 2017). Traditional organizational forms and methods of education do not fully take into account the regional, ethno-psychological, national and cultural specifics of the subjects of the educational process. Neither do they take into account the specifics of the post-graduate professional activity of the Tuvan school teacher, in particular.

In this regard, there is an objective problem of future teachers' training for the schools of the Republic of Tyva who will work on identification and development of gifted students in the IT field.

\section{Discussion}

The full-fledged work with gifted children in the field of information technologies in schools of the Republic of Tyva presupposes a teacher who will implement the individualized approach to learning. In other words, we need a computer science teacher with tutor competencies. It is the tutor's competence that facilitates the children's individual characteristics, maximally neutralizes all the factors negatively affecting manifestation and development of giftedness, and characterizes the teacher acting within the open educational space. In other words, it is the teacher's readiness and ability to individualize educational process by supporting and guiding cognitive interest through the creation of conditions for designing the students' individual educational programmes (Kovaleva, 2015).

In the process of the research we developed the content of the complex of methodically oriented courses for the future bachelors' methodological training ("Computer Science" profile) that enables to work on identification and development of 
the Tuvan children's IT-giftedness: "IT-giftedness", "Educational robotics", "Network educational initiatives", "Network Olympiads", "Ethno-psychology of Tuvan children", "Tutor support of a gifted student".

The use of regional material makes it possible to create a full-fledged and clear methodology, conscious, interested and motivated formation of methodical readiness for work with gifted children, since the students see the practical value of Computer Science as a subject. This, therefore, leads to the growth of their professional selfesteem, confidence, and ability to adapt the course of school Computer Science to regional specificity.

The methodology involves the use of educational and methodical tasks with the focus on national and regional themes. They include situational, educational, methodological, and project tasks. Here is an example of the "Schetchik-tysiachnik" ("Counter by thousands") project task from the "Educational robotics" course, the task being the development of a prototype of the farm animals monitoring system for the shepherds who own thousands of farm animals in the Republic of Tyva. For the solution of the project tasks and their implementation into a finished product as a prototype the students should 1) identify the problem, determine the final product, come up with the name of the project, justify the relevance of the project for Tyva, 2) formulate the goals and objectives, main characteristics and principles of the product's operation, determine necessary hardware and software, collect the material, describe the content of work, model and test the product, and make conclusions.

Problem: manual counting of the cattle.

Final product: cattle monitoring system.

Project name: "Schetchik-tysiachnik" ("Counter by thousands").

Relevance of project implementation: in large estates of the republic there are more than 1,000 heads of small cattle (mostly sheep) and cattle (mostly horses); such owners are called "tysiachniki" ("thousanders", owners of thousands of heads of cattle); thus, it is very difficult to manually count their cattle daily.

Goal: automation of counting the cattle.

Tasks: analysis of the final product functions; choice of materials; connection and pairing of devices; development of the algorithm of the programme code of the device; the prototype testing.

Principle of operation: non-contact RFID sensors are attached to the cattle. Located on koshara (sheep yard) gates, the "reader" of these RFIDs will automatically count the cattle in the morning during grazing and in the evening during the return to 
koshara. In case the number of the cattle who left koshara and those who return back to it is not the same, the system gives a certain sound signal.

Conclusion. The total number of cattle is counted due to the project implementation. This task can be complicated for gifted IT students: to implement the cattle identification in order to determine which animal in particular has not returned from the pasture.

Practical implementation of such life projects with the focus on national and regional themes is of great interest. This increases the students' motivation, results in sustainable knowledge formation.

Taking into account the component composition of methodical readiness and its content, we have worked out the criteria, indices and levels of the future bachelors' of education methodical readiness ("Computer Science" profile) to work with gifted Tuvan children (Table).

Table

\begin{tabular}{|c|c|c|c|c|}
\hline \multirow{2}{*}{\multicolumn{2}{|c|}{$\begin{array}{l}\text { Evaluation criteria of methodical readiness } \\
\text { to work with IT-gifted children }\end{array}$}} & \multicolumn{3}{|c|}{$\begin{array}{l}\text { Levels of methodical readiness } \\
\text { (in points) }\end{array}$} \\
\hline & & low & optimal & high \\
\hline \multicolumn{2}{|c|}{ Motivational } & $29-18$ & $42-30$ & $54-43$ \\
\hline \multicolumn{2}{|c|}{ Cognitive } & $5-0$ & $11-6$ & $17-12$ \\
\hline \multirow{3}{*}{ Activity } & theoretical index & $32-0$ & $65-33$ & $96-66$ \\
\hline & practical index & $8-0$ & $11-9$ & $15-12$ \\
\hline & total score & $40-0$ & $76-42$ & $111-78$ \\
\hline \multicolumn{2}{|c|}{ Reflexive (average estimation) } & $3,3-2$ & $4,3-3,6$ & $5-4,6$ \\
\hline \multicolumn{2}{|c|}{ Total score } & $77,3-20$ & $133,3-81,6$ & $187-137,6$ \\
\hline \multicolumn{2}{|c|}{ Average value } & $19,3-5$ & $33,3-20,4$ & $46,8-34,4$ \\
\hline
\end{tabular}

The pedagogical experiment involved the first-year students who were part of the experimental (A - 13 students) and control (B - 12 students) groups. To comprehensively evaluate the levels of formation of the components of methodical readiness to work with gifted children, we have distinguished three stages:

- the first stage: after psychologically and pedagogically oriented courses, the "Information technologies in education" course in compliance with the Federal State Educational Standard, and methodically oriented courses introduced to the curriculum ("IT-giftedness", "Educational robotics", "Network educational initiatives", "Ethnopsychology of Tuvan children"), 
- the second stage: the result of mastering the "Educational Internet services" and "Telecommunication projects" courses,

- the third stage: upon completion of "Network Olympiads", "Tutor work with gifted students" courses.

Analysis of the results of the first stage of evaluating the levels of methodical readiness shows that the students see no connection between knowledge and possibility of its application in future professional activity. The next stage shows shift in the experimental group (EG) students' motivational sphere. This stage confirms the positive impact of our methodology. At the final stage of the experiment we evaluated the efficiency of the developed methodology of training future bachelors of education ("Computer Science" profile) for working on identification and development of the Tuvan students' IT-giftedness. This methodology was introduced and had been implemented for five years at the Physics and Mathematics Department of Tuvan State University; the results of methodical training of the students enrolled in the course of the next two academic years $(2013,2014)$ were evaluated (see Fig. 1).

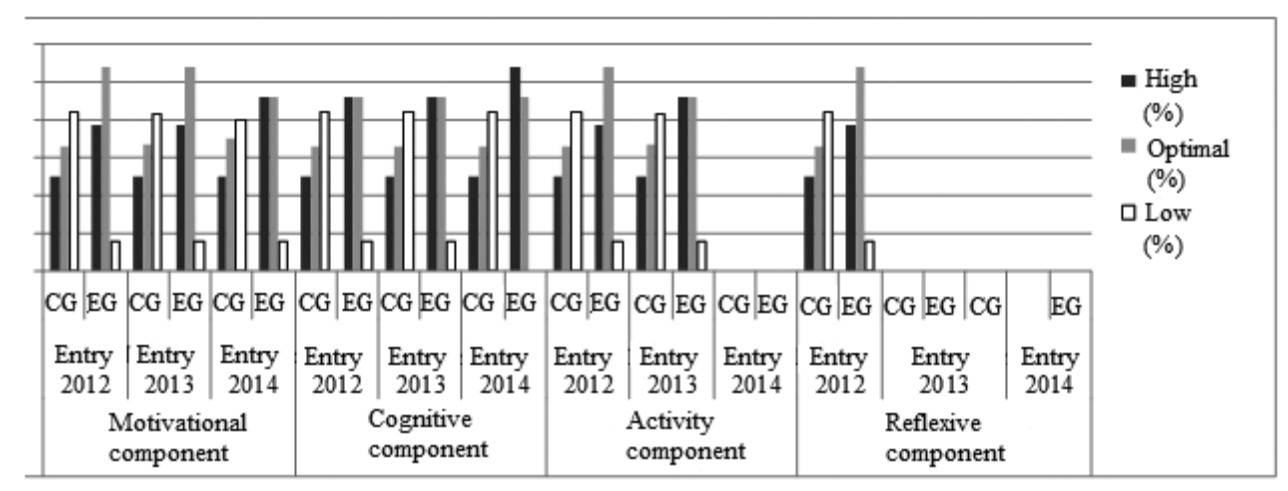

Fig. 1. Dynamics of changes in components of future teachers' methodical readiness to work with IT-gifted students (CG - control group of students, EG - experimental group of students)

The diagram shows a decrease in the number of students with a low level and an increase in the number of students with optimal and high levels of methodical readiness. Comparison of these levels as per the Pearson criterion at the end of the formative experiment confirms the hypothesis $\chi_{\text {experimental }}^{2}=15.8$, which exceeds the $\chi 2_{\text {control }}=6.0$ value. The obtained values reliably prove the existence of differences in the levels of the methodical readiness of the students in the control and experimental groups. 
Thus, the results of the pedagogical experiment show the effectiveness of the developed methods of training future bachelors of education ("Computer Science" profile) for working on identification and development of the Tuvan students' IT-giftedness.

\section{Methods and methodology}

To solve the research tasks we applied the content analysis of the issue of identification and development of IT-giftedness; pedagogical modeling was focused on the development of structural and logical model of methodological training on the basis of actualizing motivational, cognitive, activity and reflexive components of readiness; pedagogical experiment was carried out in the process of teaching the students the "Methods of teaching Computer Science" ("Computer Science" profile); correlation analysis of the results obtained by calculating the Pearson linear correlation coefficient.

\section{Conclusion/Results}

Scientifically confirmed ethno-psychological, ethno-cultural and ethnosociocultural characteristic features in Tuvan children made it possible to determine the structure and content and to reveal the essence of the future bachelors' of education methodical readiness ("Computer Science" profile) for working on identification and development of children's IT-giftedness.

We developed the supplement to the system of methodological training, consisting of a set of interrelated methodologically oriented academic courses: "IT-giftedness", "Educational robotics", "Network Olympiads", "Network educational initiatives", "Tutor support of a gifted student", and "Ethno-psychology of Tuvan children".

The training methodology is based on solving educational and methodical tasks with the focus on national and regional themes, parallel mastering of methodological training courses, blended learning, use of immersion methods and telecommunication projects. This methodology contributes to the achievement of the necessary level of methodical readiness of future bachelors of education ("Computer Science" profile) for working on identification and development of the Tuvan students' IT-giftedness.

The efficiency of the developed methodology of forming the future Computer Science teacher's methodical readiness to work on identification and development of the Tuvan students' IT-giftedness is experimentally confirmed. 


\section{References}

Agalakova, M. Iu., Luchinina, A.O. (2018). Osobennosti detskoi odarennosti [Features of children's talent]. In Vestnik Viatskogo gosudarstvennogo universiteta [Herald of Vyatka State University], 1, 75-80.

Bogoiavlenskaia, D.B. (2004). Rabochaia kontseptsiia odarennosti [Working concept of giftedness]. In Educational Studies Moscow, 2, 46-68. Available at: https://cyberleninka.ru/article/v/rabochaya-kontseptsiya-odarennosti (accessed 12 June 2019).

Buduk-ool, L.K., Aizman, R.I. (2009). Individual'no-tipologicheskie osobennosti adaptatsii studentov tuvinskoi i russkoi natsional'nosti k obucheniiu v vuze [Individualtypological characteristics of Tuvan and Russian students' adaptation to education at high school]. In Ekologiia cheloveka [Human ecology], 2, 32-38.

Buduk-ool, L.K. (2017). Vzaimosviaz' trevozhnosti i individual'no-lichnostnykh osobennostei studentov-Tuvintsev [Interrelation of anxiety and individual personality characteristics of Tuvan students]. In Uspekhi sovremennoi nauki i obrazovaniia [Success of modern science and education], 2 (6), 8-11.

Guseva, E.I., Migovich, O.I., Tikhomirova, L.F., Khitrova, G.V. (2016). Diagnostika odarennykh detei [Diagnostics of gifted children]. In Iaroslavskii pedagogicheskii vestnik [Yaroslavl Pedagogical Bulletin], 4, 13-19.

Freeman, J. (2011). Obuchenie odarennykh detei v Zapadnoi Evrope [Education of gifted children in Western Europe]. In Psikhologicheskaia nauka i obrazovanie [Psychological Science and Education], 4, 63-73.

Karelina, E.K. (2018). The Problematic Aspects of Cultural Policy in Modern Tuva. In Journal of Siberian Federal University. Humanities \& Social Sciences, 2 (11), 218-226.

Kovaleva, T.M. (2015). Novye resursy didaktiki dlia sovremennoi shkoly [New didactic resources for modern school]. In Nauka $i$ shkola [Science and school], $1,88-94$.

Krivun', M.P. (2014). Problema detskoi odarennosti v pedagogicheskoi nauke i praktike [Problem of child's endowments in a pedagogical science and practice]. In Iaroslavskii pedagogicheskii vestnik [Yaroslavl Pedagogical Bulletin], 3, 20-25.

Malikova, I.N., Khristoforova, E.D. (2017). Zarubezhnyi opyt vyiavleniia i dal'neishego soprovozhdeniia odaronnykh detei i molodezhi [Foreign experience in identifying and further accompanying gifted children and youth]. In Nauchnoissledovatel'skie publikatsii [Research publications], 2, 96-104. 
Maryukhina, V.V., Munzuk, T.T. (2018). Osobennosti ehtnicheskoi sotsializatsii podroatkov na primere Respubliki Tuva [Peculiarities of ethnic socialization of teenagers on the example of the Republic of Tuva]. In Azimut nauchnykh issledovanii: pedagogika $i$ psikhologiia [The azimuth of scientific research: pedagogy and psychology], 2 (23), 161-164.

Nikitina, E.A. (2017). Regional'nyi tsentr dlia odarennykh detei kak infrastruktura podderzhki molodykh talantov [Regional center for gifted children as the infrastructure to support young talents]. In Azimut nauchnykh issledovanii: pedagogika i psikhologiia [Azimuth of scientific research: pedagogy and psychology], 1 (18), 131-134.

Oorzhak, S. Ia., Oorzhak, K.D.-N. (2019). Ethnic Pedagogical Knowledge (Expansion of Content on the Materials of the Republic of Tuva). In Journal of Siberian Federal University. Humanities \& Social Sciences, 2 (12), 302-309.

Popova, L.V., Hieu, P.T. (2011). Predstavleniia ob odarennosti i osobennostiakh odarennykh detei (na materiale v'etnamskoi vyborki) [Representations of giftedness and gifted children's peculiarities (based on a Vietnamese survey)]. In Prepodavatel' XXI vek, 3, 343-350.

Shcheblanova, E.I. (2018). Kontseptsiia A.M. Matiushkina o tvorcheskoi odarennosti kak predposylke razvitiia tvorcheskoi lichnosti [A.M. Matyushkin's concept of creative giftedness as a presupposition of development of creative personality]. In Izvestiya of Saratov University. New Series. Series: Educational Acmeology. Developmental Psychology, 1 (25), 26-29. DOI: 10.18500/2304-97902018-7-1-26-29.

Sudneva, O.U. (2012). Odarennye deti: osobennosti i slozhnosti razvitiia [Gifted children: characteristics and complexity of development]. In Sovremennye issledovaniia sotsial'nykh problem (ehlektronnyi nauchnyi zhurnal) [Modern social research (electronic scientific journal)], 11 (19). Available at: https://cyberleninka.ru/article/v/ odarennye-deti-osobennosti-i-slozhnosti-razvitiya (accessed 19 June 2019).

Zakirov, A.A., Berman, S.S. (2014). Formirovanie gosudarstvennoi politiki v oblasti raboty s odarennymi det'mi i talantlivoi molodezh'iu v usloviiakh innovatsionnogo razvitiia Rossii [Formation of state policy in the field of working with gifted children and talented youth in the conditions of innovative development of Russia]. In Vestnik Kazanskogo tekhnologicheskogo universiteta [Herald of Kazan Technological University], 17 (16), 267-272. 


\title{
Подготовка будущих учителей к выявлению и развитию одаренности в области информационных технологий в школах Республики Тыва
}

\author{
Д.О. Куулара ${ }^{a}$ М.И. Рагулина ${ }^{\tilde{0}}$ М.П. Лапчик ${ }^{0}$ \\ ${ }^{a}$ Тувинский государственный университет \\ Россия, 667000, Кызыл, ул. Ленина, 36 \\ ${ }^{6}$ Омский государственный педагогический университет \\ Россия, 644099, Омск, наб. Тухачевского, 14
}

В статье исследуется проблема совершенствования профессиональной подготовки будуших бакалавров образования профиля «информатика» для работы по выявлению и развитию детской одаренности в ИТ-сфере в условиях культурно-образовательной среды Республики Тыва. Цель исследования - разработать такое дополнение к системе методической подготовки, применение которого обеспечит будущим бакалаврам готовность выявлять и развивать одаренность тувинских школьников в ИТ-сфере в прочессе обучения информатике.

Динамика изменений в подготовке будущих бакалавров определялась в ходе педагогического эксперимента на основе эмпирических методов: наблюдения, анкетирования, тестирования, пролонгированного педагогического эксперимента, экспертных оценок, самооченки, а также статистических методов: измерения и математической обработки экспериментальных данных.

Авторы предлагают включить в учебный план дополнительные компоненты (комплекс методико-ориентированных учебных курсов), основанные на учете этнопсихологических, этнокультурных, этносочиокультурных особенностей тувинской культурнообразовательной средьл. Экспериментальным путем доказана эффективность предложенного подхода для улучшенной подготовки бакалавров информатики к работе с одаренными детьми в тувинской школе.

Ключевые слова: бакалавр образования, информационные технологии, одаренность, этнопсихологические, этнокультурные, этносоциокультурные особенности, культурнообразовательная среда Республики Тыва.

Научная спещиальность: 13.00.00 - педагогические науки. 